\title{
Global Trends in Higher Education Financing: The United Kingdom
}

\author{
Simon Marginson
}

\begin{abstract}
Over the last 40 years, UK higher education has moved from a publicly funded system to a mixed publicly/privately funded system regulated as a tuition loans-based consumer market, in which both the student as graduate, and the higher education institution, are responsible for a significant proportion of total costs . It is nevertheless subject to robust government control. This is partly exercised indirectly through comparative assessments of institutional performance by public agencies that define common objectives and install a hierarchy based on measured performance, helping to differentiate HEIs within the market. Institutions remain partly dependent on government funding in the forms of research-related support, teaching subsidies and subsidization of the loan system through non-repayment of debt. The 2012 introduction of a $£ 9,000$ maximum fee for full-time students and $£ 6,750$ for part-time students in England, based on income-contingent repayment arrangements, was associated with a net increase in funding, growth in full-time first degree students, and a sharp fall in part-time and mature age students. Part-time students begin repayments four years after the commencement of their course of study. The long-term cost of the student loans scheme is uncertain and its sustainability is in question. After 15 years of declining funding for students, total systemic funding rose by $50 \%$ between 2000 and 2015 and per student funding also rose, but this benfitted only the research-intensive universities in the Russell group. These universities benefit most from funds allocated through the government's periodic national research assessments.
\end{abstract}

Keywords: higher education, funding, tuition, student loans, United Kingdom

\section{Introduction}

The United Kingdom (UK) is a constitutional monarchy with a parliamentary system of government, located off the northwestern coast of continental Europe. With a 2014 population of 64.5 million (World Bank, 2015), it combines England, the dominant nation, Scotland, Wales, and Northern Ireland. Scotland, Wales, and Northern Ireland each have executive governments and parliaments, and are also represented in the UK parliament at Westminster, the sole government of England. The four UK nations differ in their detailed policies on higher education funding, as will be explained. The UK's GDP of US\$2,942 billion in current prices in 2014 was fifth on the world scale, between Germany and France, and $16.9 \%$ of the economy of the United States (US). UK per capita income in 2014, US $\$ 39,167$ in purchasing power parity terms, was twenty-second in the world, compared to US\$54,630 in the US (World Bank, 2015). However, the UK is more influential in higher education and the associated research than its raw economic power would suggest. On most global rankings, it has the second largest number of world top 50 research universities after the US (e.g., ARWU, 2015), and it attracts the world's second largest number of crossborder higher education students (OECD, 2015, p. 356). More generally, since the mid1980s, associated with neoliberal financial government and the "New Public Management" 
in public administration, UK models of system and institutional organization have affected reform agendas in higher education in many nations (Regini, 2011; Shattock, 2012).

The remainder of this Section 1, the introduction, summarizes principal features of higher education in the UK. Section 2 reviews its history. Section 3 outlines the present financing system, including the tuition loans-based framework adopted in 2012. Section 4 addresses participation, equity and financing. Section 5 expands on system stratification, corporate behaviors at the institutional level, and revenue raising. The concluding Section 6 reviews the efficiency and sustainability of the financing system.

\subsection{Higher education in the UK}

The term higher education is used in the UK in two senses: in relation to institutions and in relation to levels of study and qualifications. In terms of qualifications, higher education programs exist mostly at the degree level, in contrast with the US inclusion of two-year programs. Most UK higher education institutions (HEIs) are universities. Since 2014, the UK no longer has formally required designated "universities" to conduct research and offer doctoral programs (Boliver, 2015, p. 611), but most do so. In the UK 11\% of post-school students study in Further Education Colleges (FECs), mostly at sub-degree certificate and diploma levels, but there is also a small number of degree level students. Some such places are provided on a franchising basis for universities, while others are offered by FECs in their own right. Relations between FECs and universities, including transfer, are less developed than are the links between two-year and four-year provision in the US (Parry, et al. 2012).

UK higher education is both similar to and different from the US sector. With the exception of higher education in Scotland, where no tuition is charged, the sector is explicitly modelled by government as a student loans-based market in which HEIs are expected to respond to the "customer." As in the US, in the UK norms of institutional autonomy and academic freedom are strongly entrenched. Also as in the US, university autonomy is understood in terms of the model of the university as a stand-alone firm, led by a strategically-minded president and executive that are mindful of the need for revenue and prestige. UK universities answer primarily to their own governing bodies, they form and implement business plans and from tiem to time undertake borrowings from financial organisations to raise capital. Like their American cousins, they compete with other HEIs for students, money, and good academic staff (faculty). For elite institutions; prestige is the primary motivator.

The differences are also significant. First, UK students enter higher education later than in the US, typically at 18 years, many studying for three-year degrees. Second, in the absence of state governments and large non-profit and for-profit private sectors, there is less diversity of institutional mission and type. Third, with the important exception of the separate UK nations, system governance is centralized. Self-governing UK universities, once defined as "public" and now legally classified as "private," are still shaped by government policy, regulation and funding, and in continuity with their "public" forebears. Government manages system shape, incentives and behaviors via performance-oriented comparisons like the Research Excellence Framework (REF). There is a fixed ceiling for tuition charges for UK citizens and European Union students, further reducing the scope for institution-driven variation. While the executive leaders of HEIs exercise considerable corporate freedom, their strategies and actions tend to fall within a comparatively narrow range of possibilities.

The principles of autonomy and freedom in British universities are combined with the centralized British state, with its normalizing Treasury-driven polity and uniform systems, to an extent that seems paradoxical, though it is typical of UK governance. The universities are 
not seen as outside the state like their US counterparts, not even Oxford and Cambridge, which are closest in form to the American Ivy League. Universities occupy a place in British life analogous to the national broadcaster, the BBC - both are public institutions and institutions of the middle class, formally independent while relying on a sympathetic government. Yet the annual public opinion survey by The Guardian finds that, after the National Health Service, the universities are the most trusted institutions in the UK, ahead of the police, monarchy, and judiciary (Mann, 2015). Fourth, however, the service tradition and public engagement are weaker than in the US with its land-grant ethos, independent trustees, and popular sports. Certain civic universities have a long history of region building, and in general UK higher education is closer towards US practice in relation to both localized engagement (Goddard and Vallance, 2014) and the "impact" of and commercial applications of research. Yet the instinct for external social referencing is less developed in the UK. The state is the main external agent, a de facto collective "consumer" that positions itself as operating on behalf of both students and society-which is ironic, given that, nominally, market reform is designed to free buyer-seller transactions from state control.

\section{History}

UK universities are resilient. Their economic and social weight has grown continuously, through the transition from the welfare state of 1945-1980 to the high capitalism of the neoliberal era, in which the UK's comparative international advantage is centered on the finance sector, business services, and selected technologies (Allas, 2014). Throughout the last half-century, there has been a broad consensus in support of the expansion of opportunities through growth in higher education, despite continuous changes in government policy, especially the financing arrangements and periodic under-funding.

However, UK higher education was slower off the mark than the US. The US developed diverse mass higher education before World War II and, in 1975, reached 50\% participation in two- and four-year programs. In the UK in 1950, fewer than 5\% of young people entered higher education. The Robbins Report (1963) stated as a policy principle that all qualified students who aspired to higher education should be able to enter, but growth did not fully achieve the Robbins projections (Shattock, 2012; Callender, 2014b). The UK's main period of accelerated growth was between the late 1980s and the late 1990s (Boliver, 2011, pp. 231-233) and it reached a gross tertiary enrollment ratio (GTER) of 50\% only in 1997 (Figure 1). Most of the growth was in the less prestigious universities and the polytechnics, which in 1992 were combined with the university sector in a unitary system. 


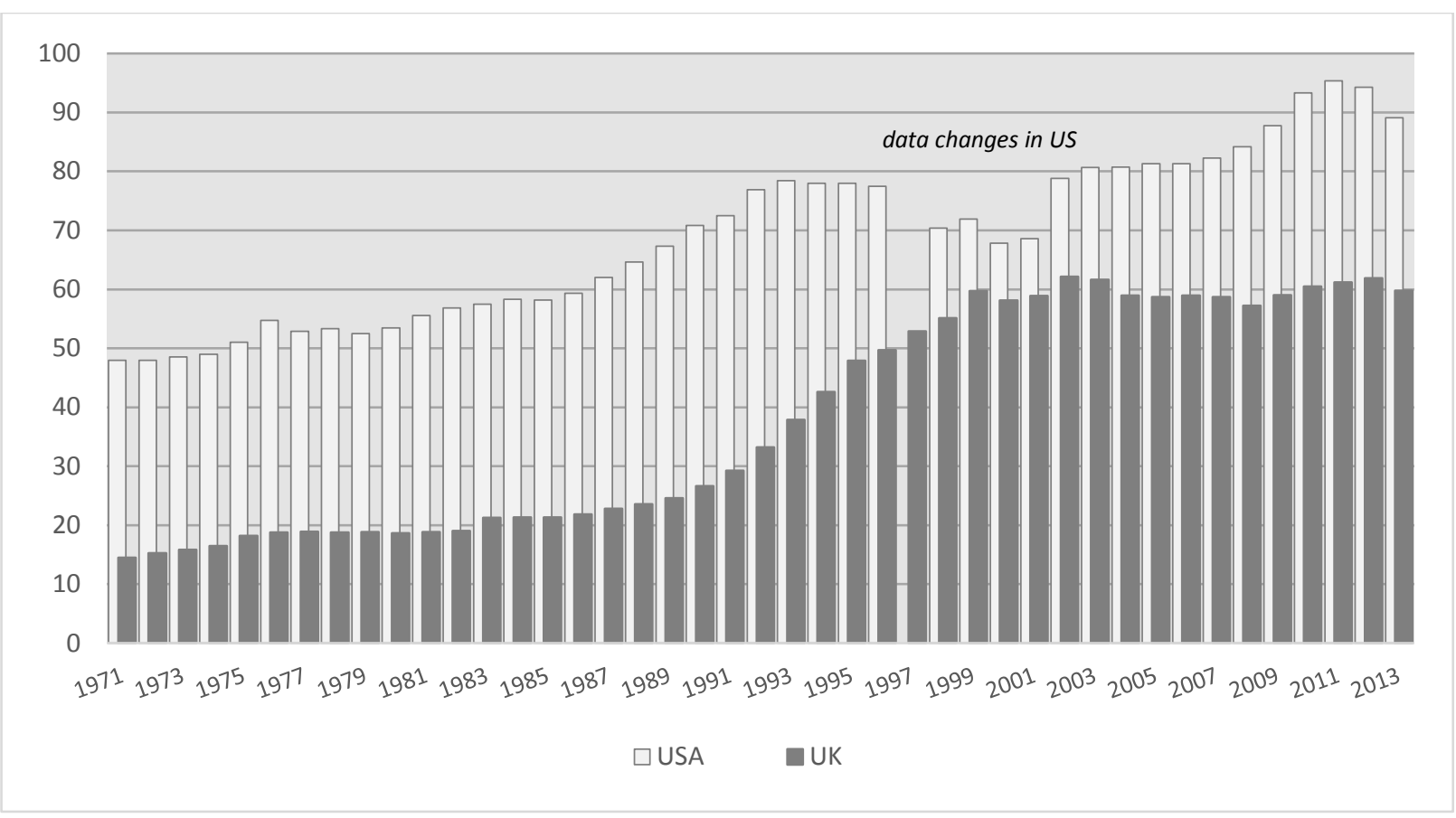

Fig. 1. Gross tertiary enrollment ratio (\%), United Kingdom (UK) and United States of America (USA), 1971-2013. Source: UNESCO (2016).

The number of students in UK higher education rose further from 1.95 million in 200001 to peak at 2.50 million in 2010-2011, before falling to 2.27 million in 2014-2015 (Figure 2 below; HESA, 2016). Between 2011 and 2015, the number of 18-20 year-olds in the UK declined from just over 2.5 million to less than 2.4 million (HEC, 2014: 28-29). ${ }^{1}$ This explains only half of the decline in enrollments, suggesting further factors. Aggregate participation remains below American levels. In 2012, the GTER in the UK was 61.9\%, compared to $94.3 \%$ in the US. However, the UK sustains higher age cohort graduation at degree level: $47.8 \%$ in 2012, compared to $40.1 \%$ in the US (UNESCO, 2016). UK higher education is concentrated at degree level, and the completion rate is higher than in the US: four out of every five UK university students graduate.

Table 1

Income of higher education institutions (\%), UK, by broad category, 1993-14 to 2013-14

\begin{tabular}{|c|c|c|c|c|}
\hline & $\begin{array}{c}1993-94 \\
\%\end{array}$ & $\begin{array}{c}2003-04 \\
\%\end{array}$ & $\begin{array}{c}2008-09 \\
\%\end{array}$ & $\begin{array}{c}2013-14 \\
\%\end{array}$ \\
\hline Tuition fees, education grants and contracts & 29.6 & 24.2 & 28.7 & 44.5 \\
\hline Funding body grants - direct subsidies to HEIs & 37.0 & 38.6 & 34.8 & 19.8 \\
\hline Research grants and contracts & 14.4 & 16.1 & 16.4 & 16.5 \\
\hline Endowments and investment income & 2.2 & 1.4 & 1.4 & 1.1 \\
\hline Other income & 16.8 & 19.6 & 18.7 & 18.1 \\
\hline TOTAL & 100.0 & 100.0 & 100.0 & 100.0 \\
\hline
\end{tabular}

Source: HESA, 2016

The trend from elite to mass and high participation education (Marginson, 2016) and the later fluctuations in total UK enrollments were accompanied by changes in financing 
mechanisms. In 1975, the high point of public funding per student, UK higher education consisted of predominantly publicly funded universities based on formal equivalence, with funding distributions on the basis of entitlement. By fits and starts it was changed into a mixed public and private funding system, modelled as a tuition-based market ordered not by prices, but by the positional hierarchy in higher education, mediated by performance competition. There have also been changes in student composition, as will be discussed.

Prior to World War II, a third of university income was from student tuition and a third from government. After the war, tuition diminished and dependence on government grew (Shattock, 2012, p. 12). Funding per student rose sharply between the late 1940s and the mid-1970s, faltering in the second half of the 1960s. It then fell sharply until the early 1980s, rose in the next four years, a period of little enrollment growth, and resumed its downward trajectory, which accelerated in the 1990s expansion. Between 1975 and 1995, per student funding declined by almost $50 \%$ in real terms (p. 131). Research funding grew via Research Assessment Exercise (RAE) grants - the RAE was the predecessor of the REF — and project support. This favored the leading institutions (pp. 131, 185).

In 1997, the Dearing Report recommended a standard $£ 1,000$ per year fee in place of the existing free tuition for full-time students. This was implemented in 1998 on a meanstested basis. In 2004, the UK moved to a $£ 3,000$ fee in England, funded using incomecontingent student loans, later followed by Northern Ireland and Wales. Then the 2010 recommendations of the Browne committee resulted in the introduction of a maximum $£ 9,000$ for domestic student tuition in England in 2012, with a cap of $£ 6,000$ in private institutions (HEC, 2014, p. 31). The government also withdrew direct subsidies for teaching, except for laboratory-based disciplines and a small number of other disciplines that it was seen as in the national interest to maintain. Most universities set their fees at the maximum. To do otherwise was to position the institution below the standard level of quality, with reputational costs.

Table 1 looks at broad funding trends over 20 years, beginning in 1993-1994. What stands out is the stability of income shares between the large categories until the 2012 reforms, despite some fluctuation. However, in the five years after 2008-2009 there was a major reduction in the share of funding body grants from 34.8 to $19.1 \%$, primarily grants for teaching, while income from tuition fees rose from 28.7 to $44.5 \%$, an outcome of the introduction of the $£ 9,000$ tuition loan regime in the 2012-2013. Research funding rose until 2009-10, then dipped and slowly recovered. There was growth in income from non-credit courses such as continuing education and professional development, though this made a minor contribution to total income, and growth also in income from contract and collaborative research (HESA, 2016). This suggests an increase in entrepreneurial activity and/or engagement with localities, industry and professions.

Remarkably, given the emphasis on austerity in UK public financing as a whole, the 1975-2000 decline in per student funding has now been reversed. Between 2001-2002 and 2013-2014, total funding for higher education grew by over $50 \%$ in real terms. Funding per student also increased (Wolf and Jenkins, 2015). There was a spike in funding after the 2012 reforms; no doubt this smoothed the introduction of the $£ 9,000$ tuition regime. However, the improved resourcing per student was largely centered on research-intensive universities in the Russell Group, enhancing system stratification (see below).

Government has been less generous with funding for student living costs. In 1990, the Education (Student Loans) Act froze means-tested student maintenance grants at the 19891990 levels and introduced loans to supplement the grants (Callender, 2015). In 1992-1993, higher education students from families with an annual household income of less than $£ 10,000$ received an annual maintenance grant of $£ 2,989$, tapering off to $£ 179$ at an income of $£ 20,000$. The value of and eligibility for maintenance grants later declined, and grants 
were abolished altogether for 1999-2000. That decision was partly reversed in 2004-2005 when grants were reintroduced at $£ 1,040$ a year, with a variation in 2006-2007 of up to $£ 2,700$ for the poorest students. By 2015-2016 the maximum grant was $£ 3,387$ for students from households with incomes of $£ 25,000$ or less, tapering off at $£ 42,620$. At the same time maintenance loans continued (Dearden et al., 2015, p. 8). Maintenance grants were again wholly replaced by a universally loans-based system in 2016.

\section{Higher education financing in 2015-2016}

In 2014-2015, 159 UK HEIs provided higher education, excluding FECs and the private sector, organized in a national system with a common legal framework and financial accountability requirements. In 2013-2014, total sector income was $£ 30.7$ billion in current prices (HESA, 2015; UUK, 2015a, p. 5). The income breakdown is summarized in Table 2.

Of this income, $£ 13.7$ billion (44.5\%) was derived from all forms of student fees, including $£ 3.9$ billion (12.7\%) from non-EU international students. Funding body grants constituted $£ 6.1$ billion (19.8\%), including $£ 3.2$ billion (10.4\%) for teaching and $£ 2.1$ billion $(6.4 \%)$ for research assessment-related funds. Funding body grants include specific monies in strategic innovation and teaching and learning projects (Conlon and Halterbeck, 2015, p. $10)$. Research grants and contracts, including projects, totalled $£ 5.1$ billion (16.5\%). The leading research-intensive universities received much higher proportions of their funds from research-related sources. More than half of all expenditure was directly related to staff costs. In 2014-2015, there were 403,835 staff employed by higher education provider institutions, of whom $49.1 \%$ were on academic contracts; $67.0 \%$ of the latter were classified as full-time (HESA, 2016).

"Other income" in 2013-2014 included residences and catering operations (5.7\%), health and hospital services (1.1\%), and other income for services (10.5\%). Endowment and investment funding $(1.1 \%)$ was low, but $3.2 \%$ of income was from philanthropic and nongovernment sources for research. Giving to UK universities is tied to research steering. There was only $£ 64.5$ million for intellectual property rights despite the strength of UK research science (HESA, 2016), suggesting that, unlike US universities, UK universities mostly leave direct commercialization of research to the external market. They are more active in consulting and contract research.

Table 2

Income of higher education institutions, UK, by category, 2013-2014

\begin{tabular}{|l|r|c|}
\hline & $\begin{array}{c}\text { Income } \\
\text { (£s million) }\end{array}$ & $\begin{array}{c}\text { Proportion } \\
\text { of income } \\
\text { \% }\end{array}$ \\
\hline TUITION FEES AND EDUCATION CONTRACTS & & \\
\hline Home and EU students & $8,958.0$ & 29.1 \\
\hline Non-EU students & $3,892.0$ & 12.7 \\
\hline Non-credit courses fees & 490.0 & 1.6 \\
\hline Further Education & 50.3 & 0.2 \\
\hline Research training support grants & 287.6 & 0.9 \\
\hline FUNDING BODY GRANTS & $3,187.1$ & 10.4 \\
\hline For teaching & $1,960.9$ & 6.4 \\
\hline For research & 429.3 & 1.4 \\
\hline Other recurrent grants & 396.4 & 1.3 \\
\hline Capital grants & 106.2 & 0.3 \\
\hline Further Education & & \\
\hline RESEARCH GRANTS AND CONTRACTS & \\
\hline
\end{tabular}




\begin{tabular}{|l|r|r|}
\hline Research Councils, Royal Societies, British Academy & $1,665.9$ & 5.4 \\
\hline UK-based charities & 994.8 & 3.2 \\
\hline UK central and local government, health and hospitals & 886.7 & 2.9 \\
\hline UK industry, including public corporations & 313.0 & 1.0 \\
\hline EU sources & 789.2 & 2.6 \\
\hline Non-EU sources & 378.1 & 1.2 \\
\hline Other sources & 56.4 & 0.2 \\
\hline OTHER SOURCES OF INCOME & & \\
\hline Endowment and investment income & 340.4 & 1.1 \\
\hline Residences and catering operations & $1,816.1$ & 5.9 \\
\hline Income from health and hospital authorities & 323.0 & 1.1 \\
\hline Grants from local authorities & 13.8 & 0.0 \\
\hline Income for services rendered & $1,759.6$ & 5.7 \\
\hline Income from Intellectual Property rights & 64.5 & 0.2 \\
\hline All other income & $1,579.1$ & 5.2 \\
\hline TOTAL INCOME & & 100.0 \\
\hline
\end{tabular}

Source: HESA (2016).

\subsection{Research funding}

In common with several European countries, the UK allocates research funding on the basis of both general funding and project grants. However, it was the first to allocate its general funding on a fully competitive basis in the successive Research Assessment Exercises (RAEs) in 1986, 1989, 1992, 1996, 2001, and 2008, and the REF in 2014. 
Table 3

The proportion of R\&D taking place in higher education institutions, and the role of international source income in R\&D, UK and selected comparators, 2013

\begin{tabular}{|l|c|c|}
\hline Nation & $\begin{array}{l}\text { Proportion of all R\&D } \\
\text { that was conducted in } \\
\text { higher education } \\
\text { \% }\end{array}$ & $\begin{array}{l}\text { Proportion of all } \\
\text { R\&D funding derived } \\
\text { from international } \\
\text { sources }\end{array}$ \\
\hline \% \\
\hline United Kingdom & 26.30 & 20.65 \\
\hline Netherlands & 31.78 & 14.27 \\
\hline Switzerland & 28.15 & 12.07 \\
\hline Finland & 21.52 & 11.54 \\
\hline Italy & 28.21 & 9.45 \\
\hline France & 20.75 & 7.62 \\
\hline Spain & 28.03 & 7.36 \\
\hline Denmark & 31.77 & 7.18 \\
\hline Sweden & 27.14 & 6.80 \\
\hline Canada & 39.80 & 5.95 \\
\hline Singapore & 29.05 & 5.91 \\
\hline Germany & 18.00 & 4.32 \\
\hline United States & 13.83 & 3.80 \\
\hline Russia & 9.01 & 3.03 \\
\hline China & 7.23 & 0.89 \\
\hline Japan & 13.47 & 0.52 \\
\hline South Korea & 9.24 & 0.30 \\
\hline
\end{tabular}

Source: UNESCO (2015).

These allocations produce a ratchet effect: funding rises in the year after an assessment and then declines (Wolf, 2015b, p. 51). The first RAE was developed to better protect science funding, but its lasting significance was that it institutionalized an output-based quasi-market, one with enough scope and apparent data credibility to regulate the HEI hierarchy (Bailey, 2015).

The UK is unusual in its level of dependence on foreign research income. In 2013, $20.7 \%$ of the UK's total R\&D funding was sourced from abroad, compared to $4.3 \%$ in Germany and $3.8 \%$ in the US (UNESCO, 2015). In part, this reflects the strength of UK university faculty in European schemes. For example, from 2007 to 2013, UK university researchers received the most funds of any nation under the EU's F7 research program: $€ 4.9$ billion, 70\% of F7 funding (UUK, 2015a, pp. 34, 39).

\subsection{Tuition loans}

Under a system of income-contingent tuition loans, students do not pay fees at enrollment, nor do they repay debt on a time basis as with mortgage-style loans. Annual tuition debt accumulates and students/graduates repay debt only when their income reaches a threshold level. Repayments take the form of an increase in the income tax rate. An income-contingent loans system can be varied by changing the operating rules that govern the stream of repayments. In 2016, the UK repayment threshold was an annual income of $£ 21,000$, compared to median gross annual earnings for full-time employees of $£ 27,600$ for the year ending 5 April 2015. The repayment rate was $9 \%$ of income above $£ 21,000$. The rate of interest on the outstanding balance varied from the rate of inflation to an extra $3 \%$, depending on income. Any remaining tuition debt was to be retired after 30 years. The government paid institutions for that part of tuition costs incurred as tuition debt, operating 
as a paymaster on students' behalf. The money went directly to HEIs from the Student Loans Company. It did not appear as government spending in the national budget, but required increased public borrowings (Wolf, 2015, pp. 47-48).

In 2015, the scheme was extended to postgraduate education in England, with a repayment rate of $6 \%$. Repayment of the two kinds of loans was concurrent. Thus graduates of both first- and second-degree programs faced an extra $15 \%$ in their tax rates.

Income-contingent tuition loans transfer tuition costs from the state and current taxpayers, and/or from parents and families, to students as future graduates. The fact that repayment is delayed and linked to capacity to pay blunts the behavioral effects of fees. Income-contingent student loans had been introduced in Australia in 1989. In that country, experience had shown that increases in the rate of tuition, or variations in tuition between disciplines, had little effect on the propensity to participate or tendency to discriminate against low income-family students (Chapman et al., 2014). With income-contingent tuition loans, price elasticity is low. As the UK Higher Education Commission has stated: "students do not feel or act like consumers" (HEC, 2014, p. 12). "The 'buy now pay later' nature of the money dilutes the effect of the market mechanism" (p. 44). In , the exceptions are parttime and mature aged students (p. 27), most of whom are required to repay in the year of study, when incomes exceed the threshold. In the UK part-time students are required to begin repayment within four years of the commencement of their courses of study, and the majority do not qualify for tuition loan support because of previous qualifications.

The $£ 9,000$ tuition regime in England was and is presented ideologically as a studentcentered customer market despite the absence of genuine market pressures (Marginson, 2013). If this "market" affects HEI and student behavior, it does so through cultural persuasion rather than the iron necessity of prices. The ideology of the market also obscures the continued dependence of all UK HEIs on public funding. After the 2012 reforms, higher education was supported from a mix of private and public funding as before. Private funding from the student user increased, and there was public funding from the research councils, continuing subsidies in the laboratory disciplines set initially at of $£ 1,500$ per student, and subsidization of the loans system, principally via non-repayment of part of the loan debt which was written off after thirty years and was not passed on to descendants.

In 2015, the Institute for Fiscal Studies (IFS) estimated that full-time students in England would graduate with an average debt for tuition and maintenance combined of $£ 44,035$ ( $£ 29,838$ in fee debt), compared to $£ 24,754$ ( $£ 11,807$ in fee debt) if the 2012 changes had not occurred. The IFS also estimated that $73 \%$ of graduates would not repay their debt in full (HEC, 2014, pp. 11, 36-37). The Higher Education Commission predicted that between 2013 and 2044, student tuition debt would expand from $£ 46$ to 330 billion (p. 12). The UK has had no experience of long-term accumulation of student debt on a large scale, raising questions about the sustainability of the financing system (see below).

For 2015-2016, the government deregulated its control of student numbers, so that HEIs were free to admit any number of qualified students into places financed by incomecontingent tuition loans (Hillman, 2014). This allowed HEIs to expand their income at the rate of $£ 9,000$ per student and take advantage of economies of scale. However, it also increased the long-term public cost of the funding system, especially as newly participating students were likely to repay the cost of tuition at below-average rates.

\subsection{Variations between the UK nations}

There are important variations between the UK nations in tuition, maintenance grants, and loans (Conlon and Halterbeck, 2015, pp. 15-17, 95). Young unmarried undergraduates do not pay fees in Scotland. The maximum postgraduate fee is $£ 3,400$. In Northern Ireland, 
the maximum fee for all domestic students is $£ 3,805$. Wales has the $£ 9,000$ maximum, but its students studying anywhere in the UK can apply for grants of up to $£ 5,190$.

\section{Table 4}

Income from funding bodies compared to income from student tuition fees, UK nations compared, 2013-2014

\begin{tabular}{|l|c|c|}
\hline & $\begin{array}{c}\text { Income from tuition fees } \\
\text { and education contracts } \\
\%\end{array}$ & $\begin{array}{c}\text { Income from funding } \\
\text { body grants } \\
\%\end{array}$ \\
\hline England & 46.9 & 17.7 \\
\hline Scotland & 26.7 & 34.5 \\
\hline Wales & 47.4 & 18.1 \\
\hline Northern Ireland & 29.8 & 37.2 \\
\hline UK & 44.5 & 19.8 \\
\hline
\end{tabular}

Source: HESA (2016).

Table 4 sets out the respective shares of income from funding councils (direct subsidies for institutions) and income from tuition and other fees, including Student Loan Company funding (HESA, 2016). Whereas in England and Wales, income from tuition fees exceeds funding body subsidies, in Scotland and Northern Ireland the reverse is true. Conlon and Halterbeck (2015) calculate the public subsidy as $£ 8,870$ for home students in England, $£ 9,016$ in Scotland, £9,456 in Wales, and £7,721 in Northern Ireland (pp. iii, 33-39).

\subsection{Further Education and the private sector}

The funding of higher education at $£ 9,000$ per student in England contrasts with an average of $£ 2,200$ per student in all courses in the FECs, underlining the subordination of the latter in terms of ascribed social values, and encouraging student movement from further to higher education (Conlon and Halterbeck, 2015, pp. 66-67). There were 189,635 higher education enrollments in FECs in 2014-2015 (p. 93), compared to 2,266,075 in HEIs (HESA, 2016). The half-decade after 2008-2009 saw a substantial increase in FEC students at diploma and certificate level, while first degree student numbers fell; in HEIs, first degree numbers grew and sub-degree enrollments declined (UUK, 2015a, p. 11). Three-year HEI degrees proved most attractive to students (Wolf, 2015, p. 58). 


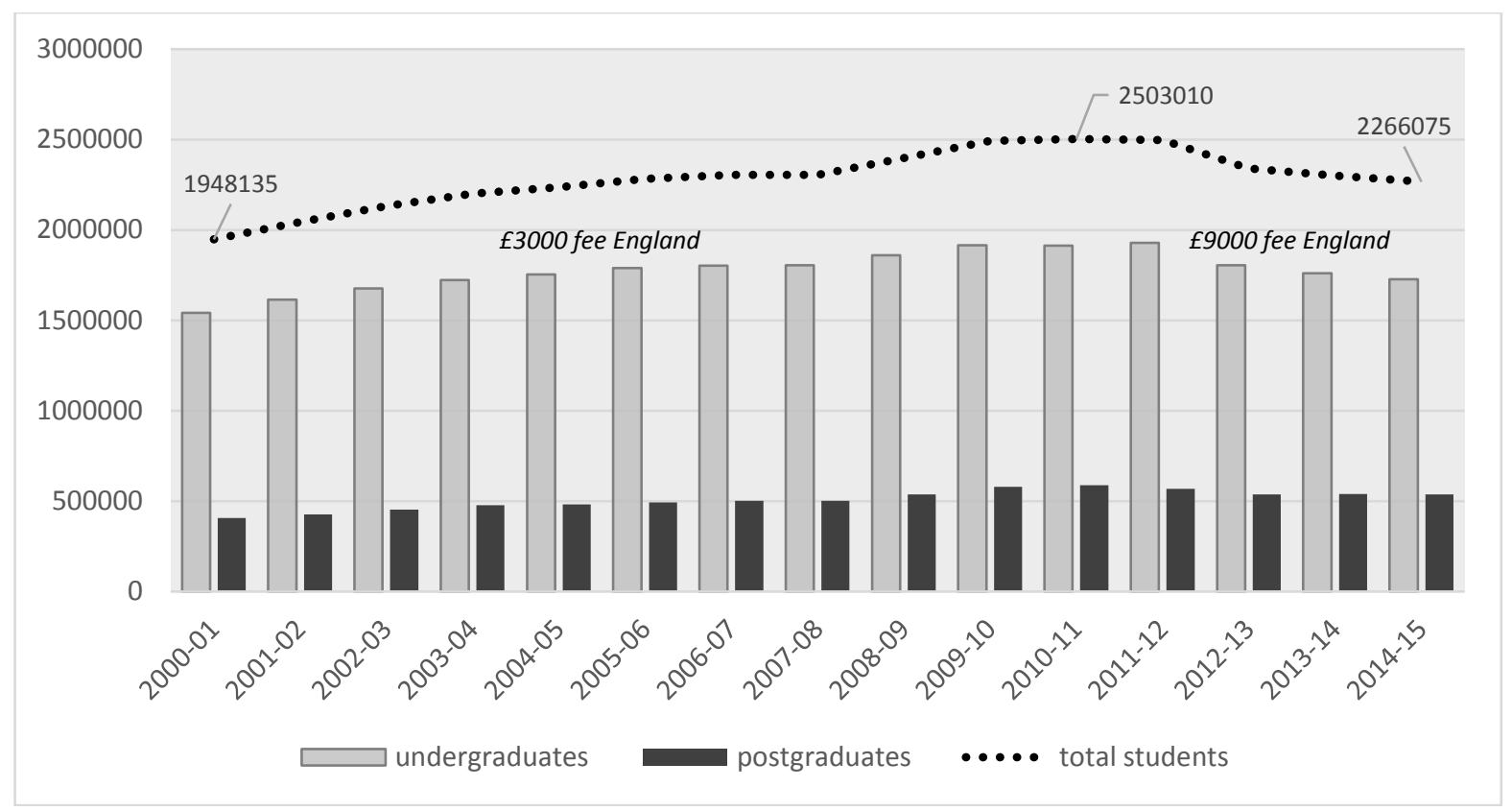

Fig. 2. Change in the number of enrolled students in UK higher education, 2000-2001 to 2014-2015. Source: HESA (2016).

In the last decade, government has encouraged private sector development. In 2010, there were ten new university designations (Temple et al., 2014, p. 19). The 2012 reforms set out to create conditions to facilitate a larger subsidized private higher education sector using income-contingent tuition loans. However, private sector fees were capped at $£ 6,000$, and most private HEIs were ineligible for research funding, positioning the sector at the lower end of the hierarchy (HEC, 2014, p. 46). Full statistics on UK private sector HEIs, known as "alternative providers," are unavailable. The number of private HEIs expanded after 2012, but they remained small. Though in 2013-2014, 53,000 students enrolled in alternative providers were covered by tuition loan arrangements, compared to 7,000 in 20102011, this was less than 4\% of all undergraduates (Wolf, 2015, p. 46). In 2015-2016, the government included private HEIs in its removal of controls over the number of subsidized students, but the licensing of new providers remained a slow process.

\section{Participation, access and financing}

Figure 2 sets down total enrollments in UK higher education from 2000-2001 to 20142015. As noted above, the fall in numbers after 2011-2012 is only partly explained by demographic factors. There was a specific and dramatic decline in part-time and mature students (Table 3; UUK, 2015, p. 13). This enhanced a trend already underway, following the removal in 2008-2009 of subsidies for students taking qualifications equivalent to or lower than the ones they had, but the specific effect of the 2012 changes is unmistakable. It is a rare case where changes in financing have been associated with direct and immediate effects on student composition. In the ten years after 2004-2005, part-time undergraduate students newly entering higher education fell by $28 \%$, and by $55 \%$ in England in the four years after 2010-2011. Part-timers were 23\% of new students in 2014-2015, compared to 40\% in 2010-2011 (Callender, 2014a, pp. 17-18; Callender, 2013). Both undergraduate and postgraduate part-time students were deterred by the $£ 6750$ fee for part-time study that was introduced in 2012-2013, which on a pro rata basis was higher than the full-time tuition fee, 
together with the requirement for repayment within four years of commencement. In 2015 the UK government announced that part-time students would be eligible for maintenance loans but with about four in five working full-time and ineligible for assistance for living costs, it remained to be seen whether that change would impact the future enrolment.

In the same ten-year period, demand for full-time undergraduate education was strong and rising, especially among 18-year olds. After a dip in England and Northern Ireland in 2012, the first year of the $£ 9,000$ fee (UUK, 2015a, pp. 8-10), numbers were soon restored. There was also growth and then plateauing in non-EU international students, with the growth driven by financial imperatives (for more discussion see below).

\subsection{Social access}

Social inequality of access is a persistent issue in the UK. To take one possible measure, in 2014 only $15.3 \%$ of disadvantaged school pupils eligible for free school meals applied to UK universities (Wyness, 2015). Inequality appears relatively entrenched. Measures of adult skills suggest greater inequalities than in most OECD nations, linked to differences in educational attainment (Green et al., 2015). Intergenerational measures of social mobility find that income mobility is lower than in most of Western Europe, but higher than in the US (Blanden, 2011, pp. 46, 58). In terms of intergenerational class fixity, mobility is lower than in the US (pp. 42-43, 54). Some studies find social mobility has declined (p. 63), though this is challenged by Gorard (2008) and Saunders (2012).

Table 3

Enrollments in UK higher education by full-time and part-time status and level of study, 2010-2011 to 2014-2015

\begin{tabular}{|c|c|c|c|c|c|c|}
\hline & 2010-11 & 2011-12 & 2012-13 & 2013-14 & 2014-15 & $\begin{array}{c}\text { Change between } \\
2010-11 \text { \& 2014-15 }\end{array}$ \\
\hline FULL-TIME & & & & & & $\%$ \\
\hline First degree & $1,251,045$ & $1,312,165$ & $1,312,335$ & $1,334,245$ & $1,340,595$ & +7.2 \\
\hline Postgraduate taught & 235,350 & 230,435 & 216,790 & 222,505 & 221,725 & -5.9 \\
\hline Postgraduate research & 74,790 & 78,975 & 79,680 & 81,940 & 83,720 & +11.9 \\
\hline PART-TIME & & & & & & $\%$ \\
\hline First degree & 214,190 & 229,200 & 216,145 & 199,610 & 183,630 & -14.3 \\
\hline Postgraduate taught & 249,860 & 228,990 & 210,520 & 205,440 & 203,545 & -18.5 \\
\hline Postgraduate research & 29,070 & 30,090 & 29,445 & 29,555 & 29,120 & +0.2 \\
\hline ALL STUDENTS & $2,503,010$ & $2,496,635$ & $2,340,275$ & $2,299,355$ & $2,266,075$ & -9.5 \\
\hline
\end{tabular}

Source: HESA (2016).

Note: For the sake of simplification, under full-time and part-time students some categories are not included, such as enrollments in foundation degrees and sub-degree diplomas and certificates. There were dramatic declines in enrollments in these categories over the time period.

Policy focuses mostly on extending the boundaries of inclusion, including the access of students from low socioeconomic status backgrounds and under-represented ethnic groups (BIS, 2015). However, academic research has focuses on not just inclusion but the stratification of higher educational opportunity, including social inequalities in access to the leading universities, especially Oxford and Cambridge. Higher education's function as a channel into the middle class is more difficult to sustain, and much more difficult to universalize when the growth of higher education outpaces the growth of opportunities for 
upward social mobility. Inevitably, as systems grow that function becomes more specifically centered on higher prestige universities, while the competition to enter such universities becomes increasingly intense. This is what has happened in the UK.

Longitudinal students suggest that while the expansion of total participation has been accompanied by an absolute increase in the number of students from under-represented social groups, at best there has been a marginal overall improvement in the access of students in these categories relative to students from other social groups. Specifically, there has been little overall change in the balance of enrollments between students from different family income quintiles or occupational status groups (Boliver, 2011). At the same time, access to elite HEIs may have become more unequal in social terms, especially for students from Afro-Carribean or South Asian background and for students who attended state schools rather than independent private schools (Boliver, 2013). A key question here concerns the social effects of the changes in tuition and maintenance grants in England and Wales and, more generally, the scope of changes in financing to affect participation. Recent research suggests financial factors play a lesser role in reproducing social inequalities in higher education than once was the case, probably due to the normalization of participation in the massified system (Marginson, 2016). In addition, as noted, income-contingent tuition loans appear neutral in socio-economic terms - although there is still insufficient research on the social effects of changes in tuition fees, including the $£ 9000$ tuition regime, and also changes to maintenance payments in the UK, especially the latter (Dearden et al., 2011),

Sullivan et al. (2015, p. 743) find that "cultural" factors rather than direct financial costs exercize the greater influence over participation. They note the nfluence of social origins, especially parental education, and private school attendance, in access to elite degrees (p. 757). Britton and colleagues (2016) demonstrate that once graduating, students from socially advantaged families experience higher earnings than others, which may help to sustain social inequalities in participation in higher education. Other studies also emphasize unequalizing effects in school and home background (e.g., Jerrim et al., 2015). Jerrim (2015) and Jerrim and Vignoles (2015) find boosting school achievement could have a greater effect in improving social equality in access than would reductions in tuition fees.

\subsection{Measures and models designed to assist under-represented social groups}

In the UK, higher education admissions are determined by performance on secondary leaving examinations. However, individual institutions have autonomy in admissions decision-making and are free to consider supplementary information. For example, admissions determinations made on the basis of academic achievement can be nuanced to take into consideration class and school type. In the UK's Code of Practice for the assurance of academic quality and standards in higher education, Section 10 recognizes this, indicating that "applicants to a higher education system that caters for mass participation will come from a wide range of backgrounds, and will demonstrate their potential to succeed in a variety of ways" (Quality Assurance Agency, 2006). Freeman (2015, p. 61) notes that "Government has increasingly encouraged universities to focus on 'potential' rather than prior academic achievement particularly in light of emerging research indicating that students from lower-performing schools perform better than peers with equivalent qualifications once they commence higher education" (e.g. Ogg, Zimdars and Heath, 2009). The Higher Education Funding Council for English (HEFCE) requires all HEIs to show that their admissions policies support" "transparency, consistency and fairness" and implement strategies to broaden participation (HEFCE, 2009; Freeman, 2015, p. 61). The UK government publishes annual data regarding individual institution's widening participation indicators through the Higher Education Statistical Agency (HESA) . Most UK universities, 
including high demand universities, sustain programs designed to enhance the participation of students from low income families and under-represented ethnic minorities. These programs extend from admissions policy, to foundation and remedial studies, to students' academic progress in the mainstream, and targeted pedagogy and assessment (Cramp, 2012). A broad range of case studies of university-level programs is provided in David (2010), Hinton-Smith (2012), Burke (2012) and Basit and Tomlinson (2012).

In contrast with higher education in the US, in the UK there appears to be limited scope for varied institutional financing models linked to social inclusion. First degree tution costs are fixed on a system-wide basis. Universities can vary the $£ 9000$ downwards for all students but this is seen as a signal of weaker quality. In relation to particular categories of student, perhaps the UK institutions have something to learn from American experience. Nevertheless, with income contingent loans the cost of tuition per se is not a principal impediment to access and small variations have negligible effects on demand. More can be achieved by varying the academic criteria for entry. This again carries reputational risks in a competitive environment, and works best in very high demand HEIs where all entrants have high scores, including those subject to positive discrimination.

There are few sources for financing either student scholarships or tuition subsidies. The role of philanthropy in student financial support is minor in comparison to the US, and confined to a few leading HEIs, including Oxford and Cambridge. For example, this enables the University of Cambridge (2016) to subsidize the tuition costs of needy students with part-cost scholaships. The number of needy students so supported is much smaller than in the University of California system, where, on the basis of family income, 40 per cent of undergraduate students pay no tuition at all (Dirks, 2015). This is because Cambridge admits a much smaller number of students from poor families than do UC Berkeley and UCLA. Again it is admissions, not financial support, that primarily limits the social composition.

\section{Business models, drivers and revenues in a stratified quasi-market}

The framing of UK higher education as a market of competing corporations, culminating in the 2012 tuition reform, is associated with three systemic tendencies. First is the development of comparative assessments of institutional performance by public agencies that define common objectives and install a hierarchy based on measured performance, which differentiates HEIs within the market. Second is the strengthening of the individual HEI as a locus of strategic planning and decision-making (Shattock, 2012). Third is the continuous growth of income-generating activities, a tendency pursued harder in some HEIs than others.

Stratification both rests on income inequalities and produces them. Davies and Zarifa (2014) show that enhanced competition and entrepreneurial activity are associated with greater stratification of HEI incomes, as shown by rising higher Gini coefficients in Canadian and US higher education. It is likely this has occurred in the UK also. But competition plays out in a system that was already hierarchical in its pre-market phase. The UK sector was distinguished from Germany, the Netherlands, and the Nordic countries by its pronounced hierarchy based on reputation, resources and research (albeit less pronounced than in the US). Market competition reinforces the pre-given hierarchy rather than subverting it. Mediation by performance comparisons largely confirms the institutional hierarchy.

\subsection{The university as quasi-firm}


The corporatization of individual HEIs has increased the scope for executive decisionmaking and planning in financial matters. UK universities carry an increasing number of functions and raise a growing proportion of their own funds. For example, they now bear the cost of capital works, with enhanced scope for borrowing to replace government capital funding. In 2014, the sector planned to invest more than $£ 15.2$ billion in infrastructure over the next four years (HEC, 2014, pp. 11, 49).

Risk has been enhanced. For example, rising interest costs and the spread of bond financing to "less financially secure parts of the sector" increase potential default (pp. 5051). Risk management is used universally through UK higher education (NJNCHES, 2011). Notwithstanding the logic of competition, there is also growing sharing of assets, such as large-scale research equipment (UUK, 2015b, pp. 58-63), which both reduces unit costs and spreads and reduces risk. But risk is also differential, being greatest in low status HEIs.

\subsection{Stratification in the UK}

Boliver (2015) uses cluster analysis to identify distinctive groupings of institutions, based on research quantity and quality, student satisfaction with teaching, endowment and investment income, spending on academic services per student, student-staff ratios, academic and also social selectivity of the student intake, and degree outcomes, using four different measures. The Universities of Oxford and Cambridge occupy the top tier, the bulk of the older universities are in a second tier, and the remaining HEIs occupy one or two lower tiers. HEIs do not stratify on the basis of student satisfaction with teaching, but are instead distinguished by other measures. Oxford and Cambridge hold exceptional endowments and offer student-staff ratios of 11 to 1 , half that of many former polytechnics (Boliver, 2015, p. 613). A total of 34.9\% of their students are drawn from independent private schools, compared to $16.1 \%$ in the second tier of universities (623).

Table 5 lists the 2010-2013 research performance of the leading 15 UK universities and their incomes for 2013-2014 (Leiden University, 2016; HESA, 2016). These data underline the association between income, standing, and the volume of high quality research.

\section{Table 5}

Combined research outputs in 2010-2013, and institutional income for 2013-2014, leading 15 UK universities as measured by the quantity of high citation papers in 2010-2013

\begin{tabular}{|c|c|c|c|c|c|}
\hline UK university & $\begin{array}{c}\text { Number of } \\
\text { students } 2014- \\
2015\end{array}$ & $\begin{array}{c}\text { Total } \\
\text { research } \\
\text { papers } \\
\mathbf{2 0 1 0 - 2 0 1 3} \\
\text { (inclusive) } \\
\end{array}$ & $\begin{array}{c}\text { Proportion of all } \\
\text { papers in top } \\
10 \% \text { of field by } \\
\text { citation rate } \\
\%\end{array}$ & $\begin{array}{c}\text { Number of } \\
\text { papers in top } \\
10 \% \text { of field } \\
\text { by citation } \\
\text { rate } \\
\end{array}$ & $\begin{array}{r}\text { Income } \\
2013-14 \\
\text { Es million } \\
\end{array}$ \\
\hline U Oxford & 26,005 & 12,935 & 17.8 & 2301 & 1174.4 \\
\hline U Cambridge & 19,515 & 12,170 & 17.3 & 2100 & 1504.5 \\
\hline U College London & 35,615 & 12,249 & 16.0 & 1959 & 1024.6 \\
\hline Imperial College London & 16,610 & 10,355 & 15.9 & 1646 & 864.6 \\
\hline U Manchester & 38,590 & 8616 & 12.3 & 1062 & 886.4 \\
\hline King's College London & 28,730 & 6358 & 15.8 & 1006 & 603.7 \\
\hline U Edinburgh & 28,880 & 6810 & 14.2 & 968 & 780.6 \\
\hline U Bristol & 21,555 & 5615 & 15.3 & 861 & 485.5 \\
\hline U Nottingham & 31,910 & 5895 & 12.4 & 729 & 571.9 \\
\hline U Southampton & 23,795 & 5269 & 12.8 & 673 & 484.3 \\
\hline U Leeds & 31,030 & 5013 & 12.8 & 644 & 587.5 \\
\hline U Birmingham & 34,160 & 5072 & 12.1 & 613 & 528.2 \\
\hline U Sheffield & 27,195 & 5023 & 12.2 & 611 & 521.3 \\
\hline U Glasgow & 26,815 & 4493 & 13.4 & 600 & 511.3 \\
\hline
\end{tabular}




\begin{tabular}{|l|l|l|l|l|l|}
\hline U Newcastle & 23,110 & 3941 & 13.2 & 520 & 449.8 \\
\hline
\end{tabular}

Source: University of Leiden, 2015; HESA, 2016.

As noted, income stratification is enhanced by national research assessment.

Entrepreneurial and service income also flows disproportionately to universities with strong reputations ("brands"). The same universities have differential fee charging and earning powers in domestic postgraduate education and international education. Teaching-related income tends to be higher in HEIs with concentrations of STEM students, who receive additional government funding. Wolf and Jenkins (2015) note that between 2011-2002 and 2013-2014, the real income of universities in the elite Russell Group rose from about $£ 7.4$ to $£ 12.2$ billion, with little change in the income of universities in other groups. While real income for teaching rose in all university groupings after the 2012 reforms, the increase was sharper in the Russell Group than for HEIs in the other groupings.

\subsection{International education}

The number of international students entering the UK grew rapidly between 2001-2002 and 2011-2012, and the UK share of the global market reached 13\% in 2012 (OECD, 2015). International students concentrate in undergraduate and short-taught Masters, and in business studies, information technology and engineering. In the last 15 years, non-EU students have generated most of the system growth at the postgraduate level (HEC, 2014, p. 25). In 2014-2015, $14 \%$ of all enrollment in UK higher education was from outside the EU, and $5 \%$ from EU countries other than the UK nations (HESA, 2016). EU students pay tuition fees on the same basis as UK students. They are eligible for tuition loans while ineligible for maintenance loans. In contrast, non-EU students are a primary source of discretionary revenues. Because international fees can be freely varied upwards, they tend to be highest in prestigious universities. UK universities have a strong incentive to expand nonEU international enrollments and have developed a high financial dependence. As Table 1 shows, in 2013-2014, non-EU students generated $12.7 \%$ of all institutional income. Undergraduate fees for non-EU students typically ranged from $£ 10,000$ to $£ 15,000$ per annum in non laboratory-based disciplines, but annual undergraduate costs at the University of Oxford were $£ 21,140$ in the classroom, while University College London charged $£ 34,800$ in its clinical programs (Matthews, 2014).

The overall economic contribution of international students, including living costs and travel, and of transnational education overseas, was an estimated $£ 17.5$ billion in 2011 (BIS and DE, 2013, pp. 59-60). The Minister for Higher Education wants $£ 30$ billion by 2020 (Ratcliffe, 2015). However, this policy goal is in tension with countervailing policy pressure to reduce net annual migration, which includes students on temporary visas. Since 2012, numbers have plateaued. Continuing increases in students from China, Hong Kong SAR, and Malaysia have been offset by declines from South Asia and Saudi Arabia (HESA, 2016). The downward pressure on numbers creates difficulties for lesser status HEIs, which, in contrast with prestigious HEIs, tend to adopt volume maximization strategies in international education because they have less access to other sources of additional revenues.

\subsection{Performance management and funding}

Within the quasi-market national system, UK HEIs are regulated and disciplined by annual performance reviews in comparative form, in which HEIs are abstracted from their 
individual historical and resource conditions and treated as equivalent players on a mythical level playing field. This both enforces conformity to the behaviors that tend to maximize performance, achieving government goals, and differentiates degree value while legitimating unequal resources, thereby advancing the leading HEIs and their users. While performance competitions are mostly framed by the government or government agencies, they include university rankings published by The Times, the Times Higher Education, the Guardian, and the business services firm QS. Certain university rankings powerfully influence decisions by students and mobile researchers (Hazelkorn, 2011).

The most important performance comparison in UK higher education is national research assessment, because of the role of research in determining prestige and monies, and because of the intensity and comprehensive scale of the process. In the 2013-2014 REF, £47 million was spent in universities and $£ 12$ million in government administrative costs (Sayer, 2014). The research assessment drive focuses on lifting research quality and on the early "impact" of research. It also encourages universities to recruit high performers by "poaching" from each other. Successful researchers offer themselves to more prestigious institutions. Both tendencies exacerbate resource concentration and stratification effects. The ratings for "impact," a criterion first introduced in 2013-2014, tended to be dominated by the traditional research leaders, which, as usual, led also on output quality (Jump, 2014).

Other system-wide performance comparisons cover graduate employment rates and salaries and student satisfaction. The survey for the Higher Education Statistics Agency's Destinations of Leavers from Higher Education Institutions is conducted six months after graduation (Jobbins, 2015). Though it is unclear to what extent graduate "destinations" are generated by higher education as distinct from family background, government, media and HEIs are preoccupied with "employability." The concern is least in research-intensive universities (Temple et al., 2014, p. 18). The National Student Survey of satisfaction is conducted towards the end of students' programs. Both comparisons function as proxy measures for the quality of teaching. There are no direct measures of student learning achievement, though the possibility has been foreshadowed (BIS, 2015a; Johnson, 2015). The government has suggested that HEIs with superior ratings for student satisfaction and "employability" could vary the domestic fee level upwards. As with the REF, the government is again positioning itself as a collective consumer on behalf of users, with financial rewards attached. In the absence of real price signals, simulation is essential to the quasi-market.

\section{Summation and conclusion}

How well does UK higher education meet the financial needs of its stakeholders: students, employers, faculty, and policy makers and regulators in government? Full-time students are attending in growing numbers, while income-contingent tuition loans protect them from immediate financial cost. Part-time students are diminishing, apparently for financial reasons. The longer-term effects of loans on graduate financial behavior are unknown. In June 2015, the unemployment rate for young graduates was 4.4\%, the lowest since the pre-2008 recession level of $2.7 \%$ (BIS, 2015b). While all faculty would like to be paid more, the degree to which UK faculty are satisfied with their level of pay relative to other professionals is unknown. However, the stakeholder that really matters is government. In this centrally managed system, it operates as the proxy for all others. While government has no satisfactory measures of graduate quality and HEI productivity, it can address questions of system efficiency and system sustainability.

\subsection{System efficiency}


The long period from 1975 to 2000 in which public funding was constrained, competitive pressures increased, and resources per student dropped sharply institutionalized a continuous pressure to reduce costs. The centrality of cost management led to the spread throughout the sector of a Chief Finance Officer (CFO)-led organizational model, matching the Treasury model in government. UK universities built an international reputation for financial management. The only ready source of private income at scale was fee revenues from international students. This helped universities to survive austerity and was the chief factor in installing a more market-driven culture (Shattock, 2012, pp. 160, 245). When resources increased again through tuition fees, the capacity for allocative efficiency persisted. The 2015 Higher Education Commission found that from 2005 to 2011, the sector achieved $£ 1.38$ billion in efficiency savings (HEC, 2014, p. 48). While the exact figure was partly based on self-reporting, the tendency is clear. However, in comparative terms, system efficiency appears to be greater in research than in education.

In research, the UK accounts for 3.2\% of global R\&D expenditure, $9.5 \%$ of scientific papers downloaded, $11.6 \%$ of citations, and $15.9 \%$ of the most highly-cited articles (HEC, 2014, p. 22). This exceptional performance is modestly funded (Allas, 2014, p. 5). In 2014, UK spending on R \& D as a proportion of GDP was 1.70\%, compared to an Organisation for Economic Co-operation and Development (OECD) country average of $2.37 \%$. The UK's GDP share was well below those of China (2.05\%), France $(2.56 \%)$, the USA $(2.74 \%)$, Germany (2.84\%), Japan (3.58\%) and South Korea (4.49\%), but ahead of Canada (1.69\%) (OECD, 2016).

In spending on tertiary education institutions, the UK allocates more, but achieves less. The OECD's Education at a Glance finds that, in 2013, the UK allocated 1.8\% of GDP in funding of tertiary education, well above the OECD average of $1.5 \%$ and ahead of Germany $(1.2 \%)$, France (1.4\%), and Japan (1.5\%), though below Korea (2.3\%), Canada (2.5\%), and the US (2.8\%) (OECD, 2015: 235). Yet the participation rate was only slightly above the OECD average. In 2013, $58 \%$ of young people entered degree level programs, compared to an OECD average of $57 \%$, and the UK's participation rate dropped to $48 \%$, compared to an OECD average of $55 \%$, when international students were excluded. On the other hand, in $2013,38 \%$ of young people were expected to graduate from degree level programs compared to an OECD average of $34 \%$ (OECD, 2015: 348, 72).

One possible explanation for the modest performance in aggregate participation relative to resources and the stronger completion rate is that a high proportion of spending, including research assessment funding, is centered on the top HEIs. This helps to sustain their research performance and means that students entering those universities might benefit from their affluence, though how much trickles down from research funding to teaching resources is an open question. Another factor may be the costs of quasi-market competition. A study of the effects of the 2012 reforms on institutional behavior found that a lesser status HEI was "devoting more management time and spending more money in efforts simply to maintain their market share" (Temple et al., 2014: 13).

In the 2015 system ranking by Universitas 21 , the UK was ranked in $24^{\text {th }}$ place out of 50 countries for "resources," but in second place for "output." The differential of 24 places was said to be "indicative of an efficient higher education sector." The UK ranked third for total publications, third for the average academic impact of articles, and second after the United States for the quality of its best universities. In the overall ranking, the UK was eight of 50 countries, but when all country scores were discounted on the basis of GDP per capita, the UK moved to second place, again indicating relative system efficiency (Williams et al., 2015). However, the Universitas 21 ranking used the 2012 expenditure data from the OECD, in which the UK's total expenditure of $1.2 \%$ was below the OECD average of $1.6 \%$ for total 
expenditure (OECD, 2014, p. 232). In 2015, the OECD calculation of the UK's spending was revised upwards, taking into account the post-2012 funding level.

The extent to which the improved funding per student of recent years has been taken to reflect better conditions for teaching and learning is unclear. The overall student-staff ratio fell only slightly: from 16.6 in 2004-2005 to 16.0 in 2013-2014 (HESA, 2016). The incidence of small group face-to-face teaching may have fallen, not increased, except at Oxford and Cambridge (Wolf and Jenkins, 2015). In some but not all HEIs, the growth of entrepreneurial and business functions in marketing, quality assurance, investments, alumni donations and facilities management has expanded professional staff in relative terms. In addition, "universities have focused on increasing the numbers of associate teaching-only staff, as well as short-term research-only staff, rather than expanding their core lecturing staff" (Wolf and Jenkins, 2015). This may have had negative implications for teaching quality.

\subsection{Longer-term sustainability}

According to the 2015 Higher Education Commission, the 2012 reform led to a 50/50 public/private split of higher education costs. The public contribution was $12 \%$ in direct subsidies and $38 \%$ in subsidization of tuition loans via the sub-commercial interest rate on tuition debt and non-payments (HEC, 2014, p. 21). This estimate rested on assumptions about future UK economic performance, graduate employment rates and earnings, government borrowing costs, and the future parameters of the scheme. In 2015, the loans subsidy, the Resource Accounting and Budgeting (RAB) Charge, was calculated as 45\%, meaning that of every $£ 1$ lent by the government, $0.45 \mathrm{p}$. would not be repaid (McGettigan, 2015a). Later in 2015, the government reduced the accounting discount rate applied to student loans from 2.0 to $0.7 \%$, reducing the RAB charge from 45 to $30 \%$ (McGettigan, $2015 \mathrm{~b}$ ) and improving the apparent sustainability of tuition loans. In fiscal terms, sustainability depends on whether the UK Department of Business, Innovation and Skills (BIS) has resources to cover the RAB charge. In effect, this places BIS in a situation of continuing debt to the UK Treasury, which also manages the terms of that debt. This enhances the capacity of Treasury to dictate higher education policy and funding.

The UK government has a range of options for reducing costs. In 2015, it did not increase the $£ 9,000$ fee ceiling for full-time undergraduates, allowing inflation to reduce net costs. It also froze the repayment threshold at $£ 21,000$ until 2021 , quickening the payback of future loans and reducing long-term unpaid debt. The government noted "fixing loan terms and conditions would give more certainty to borrowers, but would reduce the government's flexibility to manage the loan book in the future" (McGettigan, 2015c). Within the settings of the income-contingent loans system, there are further options. The government can lift the interest rate applied to accumulating tuition debt, increase the rate of repayment applied to the income tax schedules, and no longer retire debt after 30 years. The growth of resources per student in higher education since the 2012 reforms is unlikely to last.

\section{Note}

${ }^{1}$ The number of 18-20 year olds is projected to continue falling until 2021 when it bottoms out at about 2.15 million, 14\% below the 2011 level (HEC, 2014, p. 28).

\section{References}


Allas, T., 2014. Insights from international benchmarking of the UK science and innovation system. BIS Research Paper No. 03. London: BIS. Department for Business, Innovation \& Skills.

https://www.gov.uk/government/uploads/system/uploads/attachment_data/file/277090/bis14-544-insights-from-international-benchmarking-of-the-UK-science-and-innovationsystem-bis-analysis-paper-03.pdf

Bailey, T., 2015. TEF, REF and lessons from history. WONKHE, October 2. http://wonkhe.com/blogs/tef-ref-and-lessons-from-history/

Basit, T., Tomlinson, S. (eds.), 2012. Social inclusion and higher education. Bristol: Policy Press

Blanden, J., 2013. Cross-country rankings in intergenerational mobility: A comparison of approaches from economics and sociology. J. Econ. Surv., 27 (1), pp. 38-73.

Boliver, V., 2011. Expansion, differentiation, and the persistence of social class Inequalities in British higher education. H. E., 61 (3), 229-242.

Boliver, V., 2013. How fair is access to more prestigious UK universities? Brit. J. Sociol., 64 (2), 344-364.

Boliver, V., 2015. Are there distinctive clusters of higher and lower status universities in the UK? Ox. Rev. Ed., 41 (5), 608-627.

Britton, J., Dearden, L., Shephard, N., Vignoles, A., 2016. How English domiciled graduateearnings vary with gender, institution attended, subject and socioeconomic background. London: Institute of Fiscal Studies.

http://www.ifs.org.uk/uploads/publications/wps/wp201606.pdf

Burke, P., 2012. The right to higher education: Beyond widening participation. Oxford: Routledge.

Callender, C., 2013. Part-Time undergraduate student funding and financial support. In Callender, C and Scott, P (eds.) Browne and beyond: Modernizing English hgher education (130-158). London: Institute of Education Press, Bedford Way Papers.

Callender, C., 2014a. Putting part-time students at the heart of the system? In: Hillman, N. (Ed.), A Comparison of Student Loans in England and Australia. Higher Education Policy Institute (HEPI) Report No. 66. Oxford: HEPI. http://www.hepi.ac.uk/wpcontent/uploads/2014/09/Clean-copy-of-SNC-paper.pdf

Callender, C., 2014b. Student numbers and funding: Does Robbins add up? Higher Education Quarterly, 68 (2), 164-186.

Callender, C., 2015. Cost sharing and student support. Paper to seminar on 'New languages and landscapes for higher education,' University of Warwick, UK, 26-27 May. 
Chapman, B., Higgins, T., Stiglitz, J., 2014. Income contingent loans: Theory, practice and prospects. Houndmills: Palgrave.

Conlon, G., Halterbeck, M., 2015. Mind the gap: Comparing public funding in higher and further education: Resource benchmarking across education sectors in the United Kingdom. Final Report for the University and College Union. London: London School of Economics. http://londoneconomics.co.uk/wp-content/uploads/2015/11/Mind-the-gap-Public-funding-inHE-and-FE-Final-Exec-Summ.pdf

Cramp, A., 2012. Empowering non traditional students in the UK: feedback and the hidden curriculum. In T. Basit and S. Tomlinson (eds.), Social inclusion and higher education (pp. 237-254). Bristol: Policy Press,

Crawford, C., Greaves, E., 2015. Socio-economic, ethnic and gender differences in higher education participation. BIS Research Paper No. 186. London: BIS. HM Government Department for Business, Innovation \& Skills, November.

https://www.gov.uk/government/uploads/system/uploads/attachment_data/file/474273/BIS15-85-socio-economic-ethnic-and-gender-differences.pdf

David, M. (ed.), 2010. Improving learning by widening participation in higher education. Oxford: Routledge.

Davies, S., Zarifa, D., 2012. The stratification of universities: Structural inequality in Canada and the United States. Res.Soc. Strat., Mob., 30, 143-158.

Dearden, L., Fitzsimons, E., Wyness, G., 2011. The Impact of tuition fees and support on university participation in the UK. London: Centre for the Economics of Education, London School of Economics. http://cee.lse.ac.uk/ceedps/ceedp126.pdf

Department for Business, Innovation and Skills, BIS, 2015a. Fulfilling our potential: Teaching excellence, social mobility and student choice. London: BIS.

https://www.gov.uk/government/uploads/system/uploads/attachment_data/file/474227/BIS15-623-fulfilling-our-potential-teaching-excellence-social-mobility-and-student-choice.pdf

Department for Business, Innovation and Skills, BIS, 2015b. Graduate labour market statistics, April-June Q2 2015.

https://www.gov.uk/government/uploads/system/uploads/attachment_data/file/458101/BIS15-484-graduate-labour-market-statistics-Q2-2015.pdf

Department for Business, Innovation and Skills and Department for Education, BIS and DE, 2013. International education: Global growth and prosperity - accompanying analytical narrative. London: BIS and DE.

https://www.gov.uk/government/uploads/system/uploads/attachment_data/file/340601/bis13-1082-international-education-accompanying-analytical-narrative-revised.pdf

Dirks, N., 2015. The future of world-class universities. University World News, 384, 2

October.

http://www.universityworldnews.com/article.php?story=20151001004022774\&query=dirks 
Freeman, B., 2015. Who to admit, how and at whose expense? International comparative review of higher education admissions policies. Unpublished paper. Melbourne: University of Melbourne.

Goddard, J., Vallance, P., 2014. the University and the city (regions and cities). Milton Park: Routledge.

Gorard, S., 2008. A reconsideration of rates of social mobility in Britain: Or why research impact is not always a good thing. Brit. J. Sociol. Educ., 29 (3), 317-324.

Green, A., Green, F., Pensiero, N., 2015. Cross-country variation in adult skills: Inequality why are skill levels and opportunities so unequal in Anglophone countries? Comp. Educ. Rev.,59 (4), 595-618.

Hazelkorn, E., 2011. Rankings and the reshaping of higher education: The battle for worldclass excellence. Houndmills: Palgrave Macmillan.

Higher Education Commission, 2014. Too good to fail: The financial sustainability of higher education in England. http://www.policyconnect.org.uk/hec/research/report-too-good-failfinancial-sustainability-higher-education-england

Higher Education Funding Council for England (HEFCE), 2009. Request for widening participation strategic assessment. Bristol: HEFCE 2009/01.

Higher Education Statistics Agency, HESA, 2016. Data on higher education. https://www.hesa.ac.uk/free-statistics

Hillman, N., 2014. A guide to the removal of student number controls. Higher Education Policy Institute (HEPI) Report No. 69. Oxford: HEPI. http://www.hepi.ac.uk/wpcontent/uploads/2014/09/Clean-copy-of-SNC-paper.pdf

Hinton-Smith, T., 2012. Widening participation: Casting the net wide? Houndmills: Palgrave Macmillan.

Jerrim, J., Vignoles, A., 2015. University access for disadvantaged children: A comparison across English speaking countries. H. Educ., 70 (6), 903-921.

Jerrim, J., 2013. Family background and access to 'high status' universities. London: The Sutton Trust. http://www.suttontrust.com/wp-content/uploads/2014/08/john-jerrim-reportfinal-4.pdf

Jerrim, J., Chmielewski, A., Parker, P., 2015. Socioeconomic inequality in access to highstatus colleges: A cross-country comparison. Res. Soc. Strat. Mob., 42, 20-32.

Jobbins, D., 2015. Graduates face good job prospects. University World News, 16 January, Issue 350. http://www.universityworldnews.com/article.php?story=20150116090700541

Johnson, J., UK Minister for Higher Education, 2015. Teaching at the heart of the system. A speech at the Universities UK, Woburn House, Tavistock Square, delivered on 1 July. https://www.gov.uk/government/speeches/teaching-at-the-heart-of-the-system 
Jump, P., 2014. It may not be a revolution, but impact's effect is felt. Times Higher Education, 18 December, 6-7.

Mann, J., 2015. Britain uncovered survey results: The attitudes and beliefs of Britons in 2015. The Guardian, April 19. http://www.theguardian.com/society/2015/apr/19/britainuncovered-survey-attitudes-beliefs-britons-2015

Marginson, S., 2013. The impossibility of capitalist markets in higher education. J. Educ. Pol., 28 (3), 353-370.

Marginson, S., 2016. High participation systems of higher education. J. H. Ed. [in press].

Matthews, D., 2014. Pressure gauges. Times Higher Education, 21 August, 28-35.

McGettigan, A., 2015a. The Accounting and Budgeting of Student Loans. Higher Education Policy Institute (HEPI) Report No. 75. Oxford: HEPI. http://www.hepi.ac.uk/wpcontent/uploads/2015/05/Accounting-and-Budgeting-FINAL.pdf

McGettigan, A., 2015b. Spending review: Loans, RAB and the discount rate, WONKHE, 27 November. http://wonkhe.com/blogs/spending-review-2015-loans-rab-and-the-discount$\underline{\text { rate/ }}$

McGettigan, A., 2015c. Spending review: Loan repayment freeze is a tax on social mobility. WONKHE, 26 November. http://wonkhe.com/blogs/spending-review-loan-freeze-is-a-taxon-social-mobility/

New Joint Negotiating Committee for Higher Education Staff, NJNCHES, 2011. an Insider's guide to finance and accounting in higher education. New JNCHES Sustainability Issues Working Group. Universities and Colleges Employers Association (UCEA) in association with the British Universities Finance Directors Group (BUFDG). http://www.ucea.ac.uk/download.cfm/docid/0164EBE6-6AFD-423E-994B6E75980EA62D

Office for National Statistics, UK, 2015. Annual survey of hours and earnings: 2015 provisional results.

http://www.ons.gov.uk/employmentandlabourmarket/peopleinwork/earningsandworkinghou rs/bulletins/annualsurveyofhoursandearnings/2015provisionalresults

Ogg, T., Zimdars, A, Heath, A., 2009. Schooling effects on degree performance: A comparison of the predictive validity of aptitude testing and secondary school grades at Oxford University. British Educational Research J., 35 (5), 781 807.

Organisation for Economic Cooperation and Development, OECD, 2014. Education at a Glance, 2014. Paris: OECD.

Organisation for Economic Cooperation and Development, OECD, 2015. Education at a Glance, 2015. Paris: OECD. 
Parry, G., Callender, C., Scott, P., Temple, P., 2012. Understanding higher education in further education institutions. BIS Research Paper Number 69. London: Department of Business, Innovation and Skills, UK government.

Quality Assurance Agency for Higher Education, United Kingdom, 2006. Code of practice for the assurance of academic quality and standards in higher education. Mansfield: The Quality Assurance Agency for Higher Education.

GA_PRGTIPBrooksQAACodeOfPractice.pdf

Ratcliffe, R., 2014. REF 2014: Why is it such a big deal? The Guardian, 18 December. http://www.theguardian.com/higher-education-network/2014/dec/17/ref-2014-why-is-itsuch-a-big-deal

Regini, M., 2011. European universities and the challenge of the market: A comparative analysis. Cheltenham: Edward Elgar.

Robbins, L., 1963. Higher Education: Report. London: Her Majesty’s Stationery Office.

Saunders, P., 2012. Social Mobility Delusions: Why so much of what politicians say about social mobility in Britain is wrong, misleading or unreliable. London: CIVITAS.

http://www.civitas.org.uk/content/files/socialmobilitydelusions2012.pdf

Sayer, D., 2014. Five reasons why the REF is not fit for purpose. The Guardian, 15

December. http://www.theguardian.com/higher-education-network/2014/dec/15/research-

excellence-framework-five-reasons-not-fit-for-purpose

Shattock, M., 2012. Making Policy in British Higher Education 1945-2011. Maidenhead:

McGraw-Hill and Open University Press.

Sullivan, A., Parsons, A., Wiggins, R., Heath, A., Green, A., 2014. Social origins, school type and higher education destinations. Ox. Rev. Educ., 40 (6), 739-763.

Temple, P., Callender, C., Grove, L., Kersh. N., 2014. Managing the student experience in a shifting higher education landscape. York: The Higher Education Academy.

https://www.heacademy.ac.uk/sites/default/files/resources/managing the student_experienc e.pdf

United Nations Educational, Social and Cultural Organisation, UNESCO, 2015. UNESCO Science report: Towards 2030. Paris: UNESCO.

United Nations Educational, Social and Cultural Organisation, UNESCO, 2016. UNESCO Institute for Statistics data on education. http://data.uis.unesco.org/

Universities UK, 2015a. Patterns and trends in UK higher education 2015. London:

Universities UK.

http://www.universitiesuk.ac.uk/highereducation/Pages/PatternsAndTrends2015.aspx\#.Vq_i $\underline{\text { 0VIvtE4 }}$

Universities UK, 2015b. Efficiency, effectiveness and value for money. London: Universities UK. 
http://www.universitiesuk.ac.uk/highereducation/Pages/EfficiencyEffectivenessValueForMo ney.aspx\#.Vq_hDVIvtE4

University of Cambridge, 2016. Information for undergraduate applicants.

https://www.cambridgetrust.org/scholarships/key-points-for-undergraduate-applicants/

University of Leiden, 2016. CWTS Leiden Ranking 2015.

http://www.leidenranking.com/ranking

Willetts, R., 2015. Issues and ideas on higher education funding: Who pays? Who benefits?

London: The Policy Institute at King's College London http://www.kcl.ac.uk/sspp/policyinstitute/publications/Issues-and-ideas-for-an-incoming-government.pdf

Williams, R., Leahy, A., de Rassenfosse, G., Jensen, P., 2015. U21 ranking of national higher education systems. Melbourne: Melbourne Institute of Applied Economic and Social Research, University of Melbourne.

http://www.universitas21.com/RelatedFile/Download/658

Wolf, A., 2015. Heading For the precipice: Can further and higher education funding policies be sustained? London: The Policy Institute at King's College London and Digital Science. http://www.kcl.ac.uk/sspp/policy-institute/publications/Issuesandideas-alison-wolfdigital.pdf

Wolf, A., Jenkins, A., 2015. Where does the money come from and where does it go? Understanding income and expenditure in the UK university system. Paper to seminar at the UCL Institute of Education, 2 December.

World Bank, 2015. Data and statistics. http://data.worldbank.org/indicator

Wyness, G., 2015. Paying for higher education: What do the UK political party policies mean for universities, graduates and students?

http://blogs.lse.ac.uk/impactofsocialsciences/2015/04/29/paying-for-higher-education/

\section{Contact details}

(Dr.) Simon Marginson

Director ESRC/HEFCE Centre for Global Higher Education

Professor of International Higher Education

UCL Institute of Education

University College London

20 Bedford Way

London WC1H 0AL

United Kingdom

Email: s.marginson@ioe.ac.uk

Mobile: +44 (0) 7876323949 


\section{Bio}

Simon Marginson is Professor of International Higher Education at the UCL Institute of Education, University College London, and Director of the ESRC/HEFCE Centre for Global Higher Education. He is also Joint Editor-in-Chief of the journal Higher Education. 